\title{
REALIZACJA PROJEKTÓW EKOINNOWACJI W RAMACH REGIONALNEGO PROGRAMU OPERACYJNEGO WOJEWÓDZTWA DOLNOŚLĄSKIEGO
}

\author{
Katarzyna Knapik, Tomasz Nitkiewicz \\ Politechnika Częstochowska \\ Wydział Zarządzania
}

\begin{abstract}
Streszczenie: Artykuł podejmuje problematykę wpływu funduszy UE na proces wdrażania ekoinnowacji w przedsiębiorstwach. Analiza porównawcza obejmuje ocenę poziomu ekoinnowacyjności w województwie dolnośląskim w zestawieniu z wynikami osiągniętymi w skali ogólnokrajowej. Celem artykułu jest analiza bezpośredniego wsparcia ekoinnowacji w przedsiębiorstwach w ramach Regionalnego Programu Operacyjnego Województwa Dolnośląskiego w latach 2007-2013. Dla potrzeb analizy przeprowadzono klasyfikację projektów na innowacyjne oraz ekoinnowacyjne. Następnie porównano obie grupy projektów w zakresie ich liczebności, budżetu oraz wielkości wsparcia. Kluczowe czynniki, które zostały uwzględnione w artykule, to liczba projektów obejmujących ekoinnowacje, łączna wartość budżetu oraz średnia wartość budżetu poszczególnych rodzajów projektów.
\end{abstract}

Słowa kluczowe: ekoinnowacje, fundusze strukturalne UE 2007-2013, PO Innowacyjna Gospodarka, RPO Województwa Dolnośląskiego

DOI: $10.17512 /$ znpcz.2017.4.1.02

\section{Wprowadzenie}

Od początku idei zrównoważonego rozwoju towarzyszą innowacje i rozwój technologiczny jako jeden z kluczowych warunków osiągnięcia jego celów. Ekoinnowacje stanowią jeden z zasadniczych nośników rozwoju technicznego i technologicznego, zarówno w zakresie produkcji, jak i konsumpcji, który ma potencjał osiągnięcia celów wyznaczonych przez zrównoważony rozwój, skutecznie integrując w sobie trzy jego kluczowe płaszczyzny: gospodarczą, społeczną i ekologiczną. $\mathrm{W}$ związku z powyższym rozwój tego potencjału w dużej mierze powierzono nie tylko sektorowi przedsiębiorstw, ale również instytucjom ten sektor wspierającym, aby osiągnąć masę krytyczną zaangażowania i uruchomić ekoinnowacje jako koło zamachowe zmian w zakresie produkcji, konsumpcji, oddziaływań środowiskowych czy społecznych. Właśnie publiczne wsparcie ekoinnowacji, zarówno w zakresie polityk UE, jak i polityk krajowych, ma stać się gwarantem osiągnięcia takiego efektu, a być może wygenerowania zjawiska synergii pomiędzy prywatnym i publicznym zaangażowaniem w rozwój ekoinnowacji. 


\section{Rola ekoinnowacji}

Ekoinnowacje stanowią jeden $\mathrm{z}$ ważniejszych kierunków rozwoju, bowiem przyczyniają się zarówno do wzrostu konkurencyjności przedsiębiorstw, jak również do eliminacji negatywnych skutków wzrostu gospodarczego dla środowiska naturalnego. Mają też zasadnicze znaczenie dla wdrażania zrównoważonego rozwoju, wpisując się w nowy paradygmat rozwiązań, które mają ,pozytywny wpływ na globalne społeczeństwo i ekosystem, bez pozbawiania zarazem przedsiębiorców możliwości rozwoju i osiągania celów" (Katoła 2012, s. 69).

„Eko-innowacje to innowacje w dowolnej postaci, których wynikiem lub celem jest znaczący i widoczny postęp w kierunku osiągnięcia zrównoważonego rozwoju poprzez zmniejszenie negatywnego wpływu na środowisko, zwiększenie odporności na obciążenia środowiskowe lub osiągnięcie efektywniejszego i bardziej odpowiedzialnego korzystania z zasobów naturalnych" (EC 2011, s. 2).

Dodatkowe wsparcie ekoinnowacji ze środków publicznych ma przyczynić się do wywołania efektu synergii, zwłaszcza w obszarze korzyści środowiskowych. Bezpośrednie i pośrednie wspomaganie rozwoju i wdrażania ekoinnowacji stanowi jeden $\mathrm{z}$ aktualnych priorytetów polityki UE wobec przedsiębiorstw (Nitkiewicz 2012; Ociepa-Kubicka 2015).

Celem niniejszego artykułu jest sprawdzenie, jak powszechnie przyjęta polityka wspierania ekoinnowacji przekłada się na bezpośrednie wsparcie projektów ekoinnowacyjnych w programach realizowanych na poziomie regionalnym. Obiekt badań stanowi Regionalny Program Operacyjny Województwa Dolnośląskiego 2007-2013, który obejmował także bezpośrednie wsparcie wdrażania ekoinnowacji w przedsiębiorstwach.

Prace badawcze i ewaluacyjne są prowadzone w zróżnicowanym zakresie równolegle $\mathrm{z}$ realizacją projektów ekoinnowacyjnych. Nitkiewicz podjął podobną tematykę $\mathrm{w}$ odniesieniu do projektów zrealizowanych $\mathrm{w}$ ramach regionalnych programów województw łódzkiego i śląskiego (Nitkiewicz 2012; Nitkiewicz 2013). Smolnicki i Lubaczewska podjęli się analizy Regionalnego Programu Operacyjnego Województwa Dolnośląskiego w zakresie realizacji zasad zrównoważonego rozwoju, uwzględniając również potencjał projektów innowacyjnych w technologiach środowiskowych takich jak energetyka, oczyszczanie ścieków czy zagospodarowanie odpadów (Smolnicki, Lubaczewska 2013). Szpor i Śniegocki zajęli się natomiast ogólnopolskim kontekstem wdrażania ekoinnowacji, wskazując również na możliwości wykorzystania środków zewnętrznych, w tym funduszy strukturalnych UE, na ich finansowania (Szpor, Śniegocki 2012). Perspektywą przedsiębiorców w odniesieniu do ekoinnowacji zajęły się Lisiecka i Czyż-Gwiazda, realizując badania ankietowe i podejmując się oceny ich znaczenia w orientacji zarządzania (Lisiecka, Czyż-Gwiazda 2012). Pośrednio tematykę ekoinnowacji w Polsce podejmuje również Anuszewska, Podlejska, Jackiewicz i Filipek w projekcie Zrównoważona produkcja $w$ działalności przedsiębiorstw, który w latach 2010-2011 był realizowany przez PARP (Anuszewska i in. 2011). 


\section{Wsparcie innowacji w ramach Regionalnego Programu Operacyjnego Województwa Dolnośląskiego 2007-2013}

Regionalny Program Operacyjny Województwa Dolnośląskiego 2007-2013 (RPO WD) był jednym z 16 programów regionalnych realizowanych w okresie 2007-2013 dla realizacji zadań regionalnych polityki spójności i polityki regionalnej UE. Przedmiotem zainteresowania w niniejszym artykule jest bezpośrednie wsparcie przedsiębiorstw w zakresie działalności innowacyjnej, które może być wykorzystane także dla wdrażania ekoinnowacji. Bezpośrednie wsparcie przedsiębiorstw ujęto w pierwszej osi priorytetowej RPO WD.

Celem pierwszej osi priorytetowej jest wzrost konkurencyjności dolnośląskich przedsiębiorstw, głównie poprzez działania wspomagające rozwój MŚP oraz wzmocnienie i wykorzystanie potencjału sektora $B+R$. Analizie poddano działanie 1.1 „Inwestycje dla przedsiębiorstw”, którego głównym celem było wsparcie procesu inwestycyjnego przedsiębiorstw, a w szczególności MŚP, wzrost nakładów na sferę badawczo-rozwojową przedsiębiorstw oraz wykorzystanie potencjału turystyczno-uzdrowiskowego regionu (SOP RPO WD 2015).

W ramach działania 1.1 realizowane były projekty dotyczące dotacji inwestycyjnych dla przedsiębiorstw w zakresie (SOP RPO WD 2015):

- wspierania innowacyjności produktowej i procesowej o charakterze regionalnym;

- wdrażania technologii informacyjnych;

- dostosowywania przedsiębiorstw do wymogów wynikających z prawa w zakresie ochrony środowiska oraz w zakresie zwiększenia efektywności energetycznej;

- zwiększania atrakcyjności turystycznej regionu;

- realizacji inwestycji w ramach regionalnych sieci współpracy;

- rozwoju mikroprzedsiębiorstw w ich początkowej fazie rozwoju.

Oprócz bezpośredniego ujęcia w działaniu 1.1 możliwości wsparcia projektów bezpośrednio zorientowanych na poprawę $\mathrm{w}$ zakresie ochrony środowiska zawarto również pośrednie instrumenty motywujące do generowania efektów ekologicznych $\mathrm{w}$ ramach podejmowanej działalności innowacyjnej. Dotyczy to przede wszystkim ujęcia w procedurze konkursowej kryterium ochrony środowiska jako kryterium horyzontalnego, które pozwalało na uzyskanie dodatkowych punktów przy ocenie przy wykazaniu pozytywnego wpływu na środowisko (RPO WD 2014).

W latach 2007-2013 w ramach działania 1.1 RPO WD zrealizowano lub rozpoczęto 929 projektów, na które przeznaczono łączny budżet w wysokości $2630 \mathrm{mln}$ zł (http://www.mapadotacji.gov.pl/).

Dla celów porównawczych dokonano klasyfikacji analogicznych projektów, ale zrealizowanych w ramach Programu Operacyjnego Innowacyjna Gospodarka (PO IG) w ramach czwartej osi priorytetowej pt. „Inwestycje w innowacyjne przedsięwzięcia". Czwarta oś priorytetowa PO IG obejmuje następujące działania: „Wsparcie wdrożeń wyników prac B+R” (4.1), „Stymulowanie działalności B+R przedsiębiorstw oraz wsparcie w zakresie wzornictwa przemysłowego" (4.2), „Kredyt technologiczny” (4.3), „Nowe inwestycje o wysokim potencjale innowacyjnym" (4.4) (SOP PO IG 2013). W analizie nie ujęto działania 4.5, które nie było 
zorientowane na innowacje. Łącznie sklasyfikowano 1906 projektów PO IG na łączną kwotę $28221 \mathrm{mln}$ zł (http://www.mapadotacji.gov.pl/).

\section{Klasyfikacja projektów}

Przeprowadzona ocena bazuje na klasyfikacji projektów realizowanych według kryterium ekoinnowacyjności. Klasyfikacja dzieli całą populację projektów na dwie kategorie: projekty ekoinnowacyjne oraz pozostałe innowacje. Dane dotyczące projektów (tytuły projektów, krótki opis obejmujący informacje o oczekiwanych rezultatach, rodzajach innowacji i budżecie) pozyskano ze strony http://www.mapadotacji. gov.pl/ i sklasyfikowano zgodnie z przyjętymi kryteriami zaprezentowanymi poniżej. Łącznie klasyfikacja objęła 929 projektów RPO WD.

Klasyfikacja uwzględnia dwie następujące kategorie projektów:

1. bezpośrednie lub pośrednie ekoinnowacje - projekty, których bezpośrednim celem jest opracowanie i wdrożenie ekoinnowacji, lub projekty generujące efekty środowiskowe przy okazji wdrażania innych innowacji;

2. innowacje niezorientowane ekologicznie - projekty, które ani w celu głównym, ani w celach wspierających nie uwzględniają ekoinnowacji i nie prowadzą do powstania pozytywnych efektów ekologicznych.

Projekt sklasyfikowany jako ekoinnowacyjny musi zakładać osiągnięcie co najmniej jednego z następujących efektów: ograniczenie wpływów na środowisko naturalne, zwiększenie odporności na presje środowiskowe, osiągnięcie bardziej efektywnego i odpowiedzialnego użytkowania zasobów naturalnych.

\section{Analiza struktury projektów realizowanych w dzialaniu 1.1 RPO WD}

Na poniżej zamieszczonych wykresach przedstawiono strukturę projektów zrealizowanych w ramach działania 1.1 RPO WD z uwzględnieniem klasyfikacji projektów.

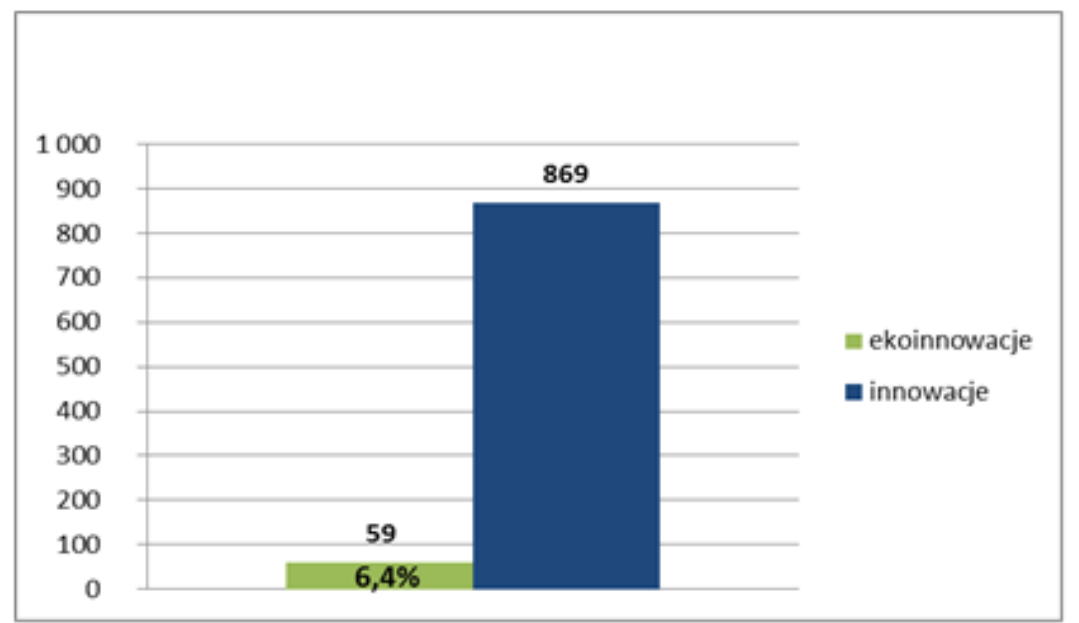

Rysunek 1. Liczba projektów realizowanych w ramach działania 1.1 RPO WD

Źródło: Opracowanie własne 
Na Rysunku 1 zilustrowano liczbę projektów realizowanych w ramach analizowanego działania 1.1 „Inwestycje dla przedsiębiorstw” RPO WD z podziałem na projekty ekoinnowacyjne oraz projekty innowacyjne. Projekty uwzględniające ekoinnowacje stanowią ok. 6,4\% całkowitej liczby projektów zrealizowanych w ramach działania 1.1 RPO WD. Największy udział projektów w ich całkowitej liczbie stanowią projekty innowacyjne, a ich liczba wynosi 869.

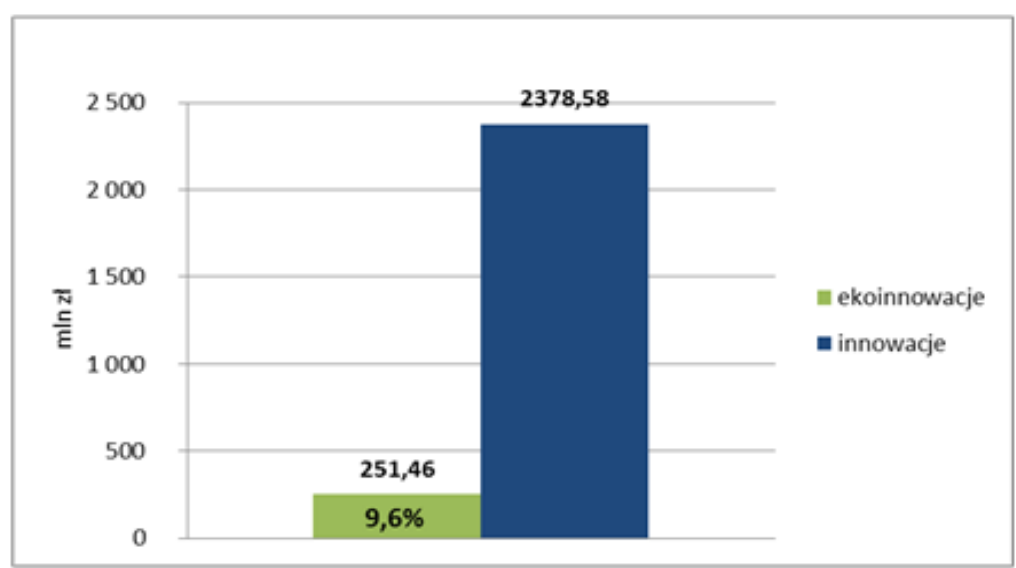

\section{Rysunek 2. Przeznaczenie budżetu działania 1.1 RPO WD}

Źródło: Opracowanie własne

Na Rysunku 2 przedstawiono całkowity budżet działania 1.1 RPO WD przeznaczony na poszczególne projekty. Projekty ekoinnowacyjne osiągają już prawie 10-procentowy udział. Wskazuje to, że powszechne przekonanie o wysokich kosztach ochrony środowiska znajduje swoje uzasadnienie także w odniesieniu do projektów ekoinnowacyjnych.

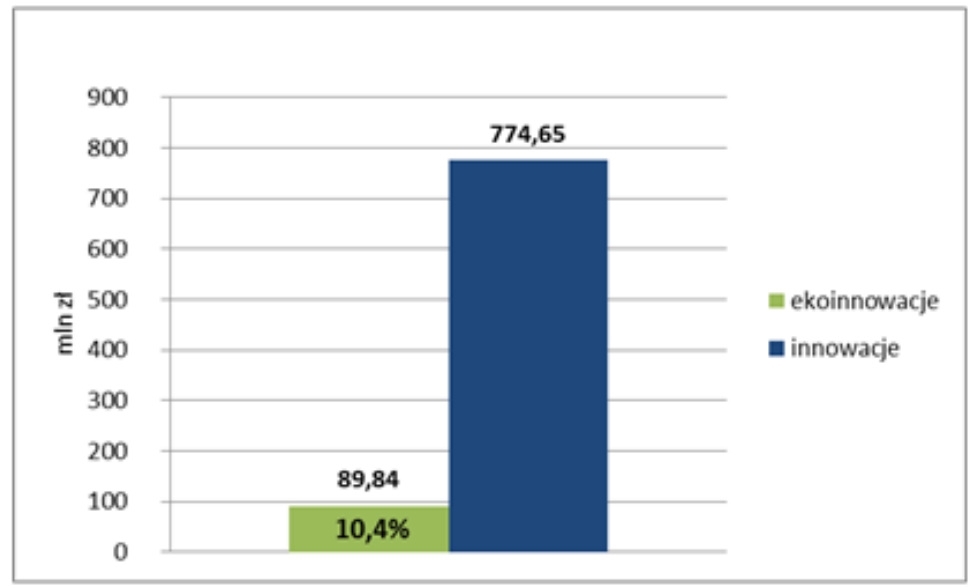

Rysunek 3. Lączna wielkość dofinansowania działania 1.1 RPO WD

Źródło: Opracowanie własne 
W przypadku łącznej wielkości wkładu dofinansowania z UE projekty ekoinnowacyjne przekraczają już próg 10\% (dokładnie 10,4\%) (Rysunek 3). Na innowacje niezorientowane ekologicznie przeznaczono wsparcie z UE w wysokości ok. $775 \mathrm{mln}$ zł. Potwierdza to większe potrzeby kapitałowe ekoinnowacji w odniesieniu do innowacji tradycyjnych, a także potencjalnie większą skłonność instytucji finansujących do finansowania w przypadku występowania efektów środowiskowych.

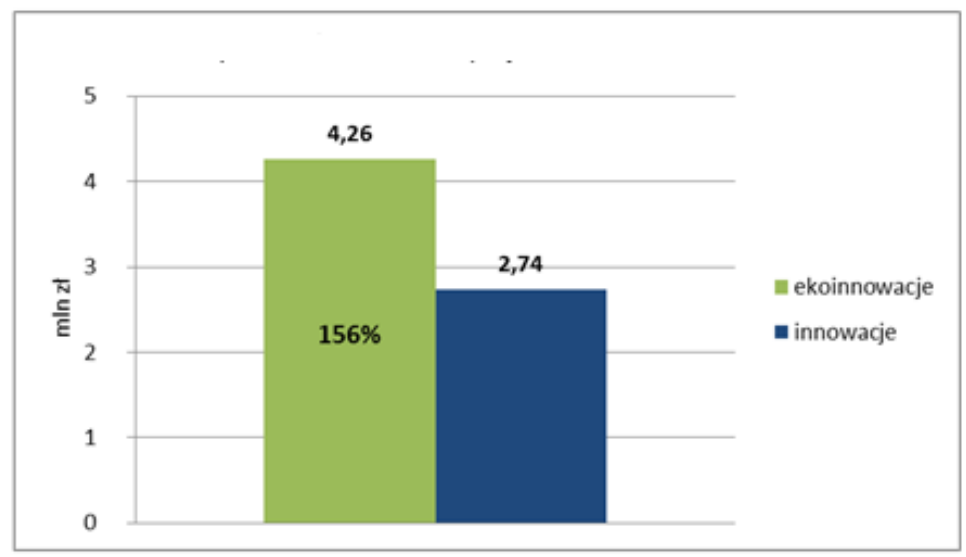

Rysunek 4. Średni budżet projektu dzialania 1.1 RPO WD

Źródło: Opracowanie własne

Na Rysunku 4 przedstawiono średni budżet projektu działania 1.1 „Inwestycje dla przedsiębiorstw" RPO WD. Jak ilustruje wykres, średni budżet dla projektów wdrażających ekoinnowacje $(4,26 \mathrm{mln}$ zł) jest znacznie wyższy od budżetu innowacji tradycyjnych $(2,74 \mathrm{mln} \mathrm{zl})$. W związku z tym projekty zorientowane na ekoinnowacje mają budżet wyższy średnio o 56\%, co potwierdza tezę o ich kapitałochłonności.

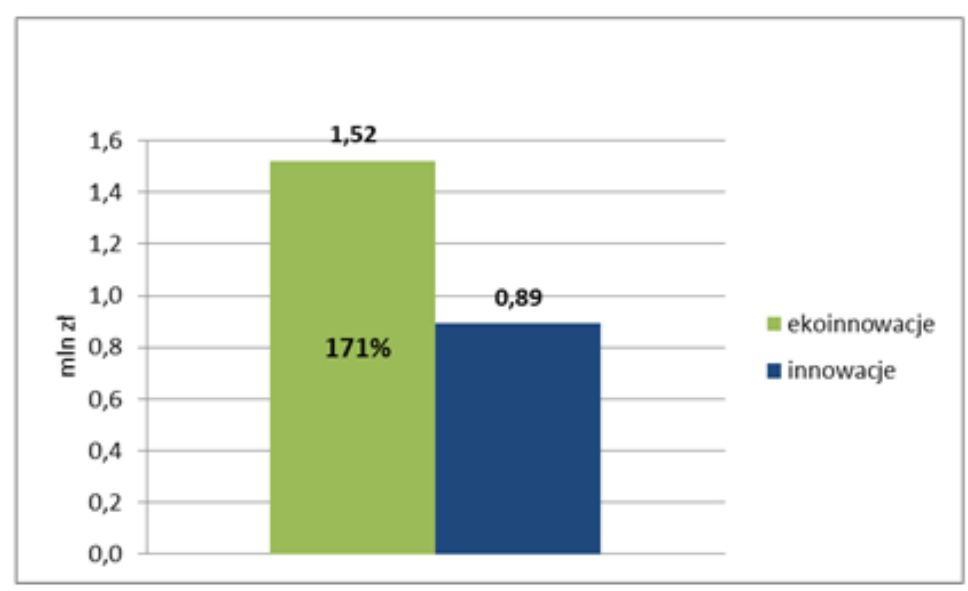

Rysunek 5. Średnia wielkość dofinansowania projektu w dzialaniu 1.1 RPO WD

Źródło: Opracowanie własne 
Średnią wielkość dofinansowania w ramach działania 1.1 RPO WD dla poszczególnych projektów przedstawiono na Rysunku 5. Podobnie jak w przypadku średniego budżetu działania 1.1, wyższy średni poziom finansowania zaobserwowano w przypadku projektów ekoinnowacyjnych. Średnia wielkość dofinansowania dla projektów ekoinnowacyjnych wynosi $1,52 \mathrm{mln}$ zł, natomiast dla projektów innowacji tradycyjnych 890 tys. zł. Dofinansowanie projektów ekoinnowacyjnych jest o $71 \%$ wyższe od tradycyjnych innowacji.

\section{Analiza porównawcza projektów realizowanych w dzialaniu 1.1 RPO WD oraz priorytecie czwartym PO IG}

Na Rysunkach 6-9 przedstawiono porównanie struktury projektów działania 1.1 RPO WD w odniesieniu do projektów wybranych działań priorytetu czwartego PO IG. Wydaje się, że najlepszym punktem odniesienia dla działania 1.1 są działania 4.1 oraz 4.4, gdyż wszystkie one obejmują bezpośrednie wsparcie innowacji w przedsiębiorstwach. Istotną różnicą jest orientacja działania 1.1 na sektor małych i średnich przedsiębiorstw. Ważnym wyróżnikiem działania 4.1 natomiast jest wymagana współpraca $z$ sektorem $\mathrm{B}+\mathrm{R}$ przy opracowaniu i wdrożeniu innowacji. Wreszcie działania realizowane $\mathrm{w}$ ramach PO IG mają znacząco większe limity dofinansowania (SOP PO IG 2013).

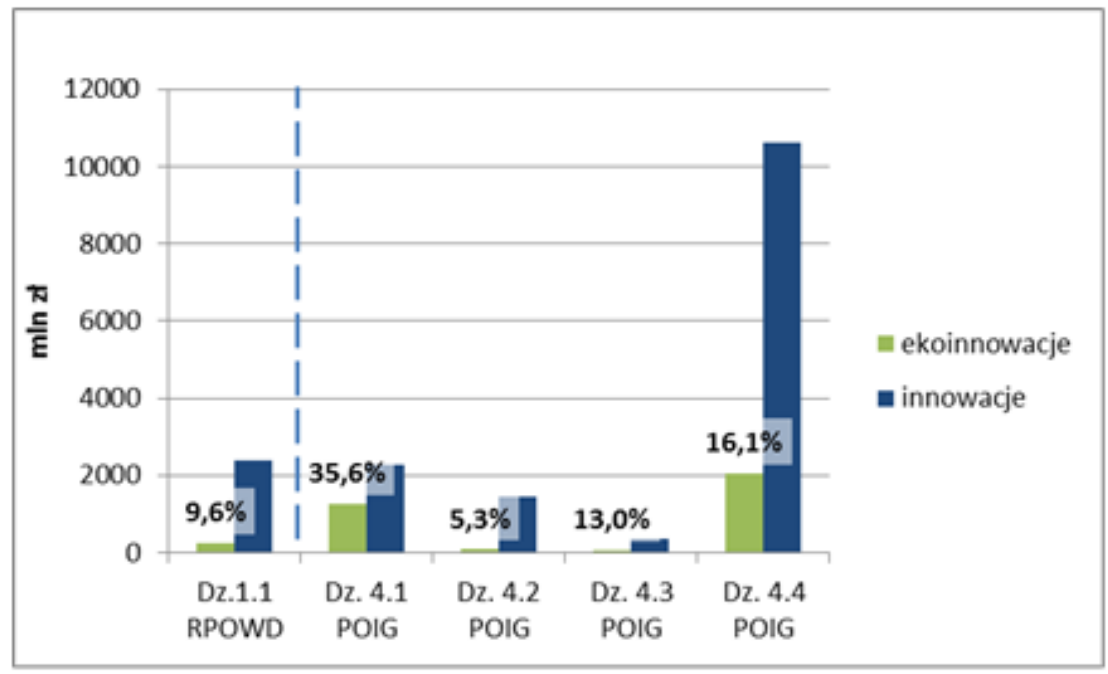

Rysunek 6. Porównanie całkowitego budżetu wybranych działań PO IG oraz dzialania 1.1 RPO WD

Źródło: Opracowanie własne

Na Rysunku 6 przedstawiono porównanie całkowitego budżetu działania 1.1 RPO WD z wybranymi działaniami priorytetu czwartego Programu Operacyjnego Innowacyjna Gospodarka. W województwie dolnośląskim finansuje się znacząco mniej projektów ekoinnowacyjnych niż w działaniach ogólnopolskich, bo zaledwie 9,6\%. 


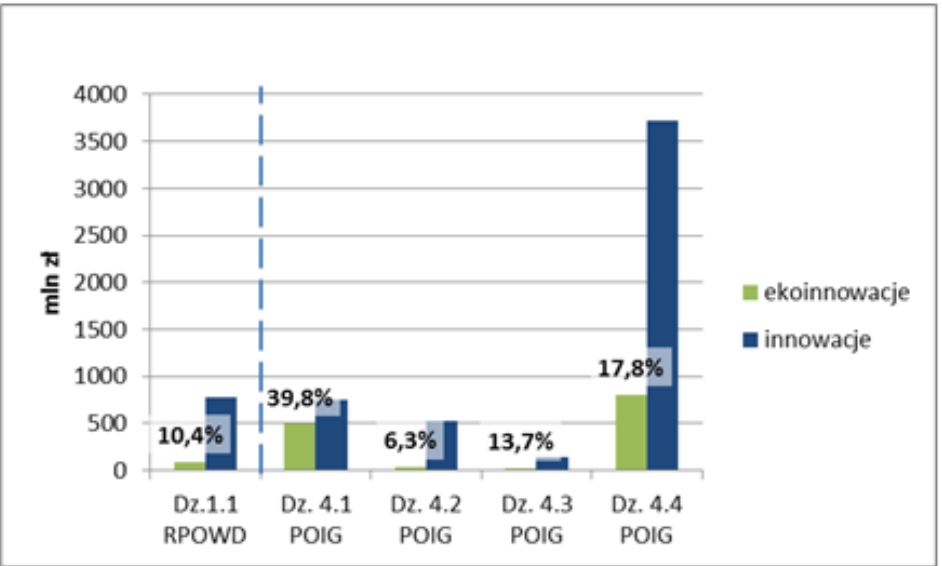

Rysunek 7. Porównanie wielkości dofinansowania projektów w wybranych działaniach PO IG oraz działaniu 1.1 RPO WD

Źródło: Opracowanie własne

Porównanie wielkości dofinansowania projektów działania 1.1 RPO WD oraz działania osi 4 PO IG zaprezentowano na Rysunku 7. Projekty ekoinnowacyjne RPO WD finansowane są zaledwie $\mathrm{w}$ wymiarze $10,4 \%$, co ma zdecydowanie mniejszy udział $\mathrm{w}$ stosunku do projektów realizowanych $\mathrm{w}$ ramach działań 4.1 (prawie 40\%) i 4.4 (prawie 18\%) PO IG, które są najbardziej zbliżone do działania 1.1. W przypadku działania 4.3 (kredyt technologiczny) ta różnica nie jest już tak istotna. Natomiast w odniesieniu do działania 4.2 różnica wypada na korzyść działania 1.1, gdyż ekoinnowacje mają tylko 6,3\% udziału w wielkości dofinansowania.

Najbardziej znaczące różnice widać jednak przy analizie średniej wielkości budżetu i średniej wielkości dofinansowania, co przedstawiają kolejno Rysunek 8 oraz Rysunek 9.

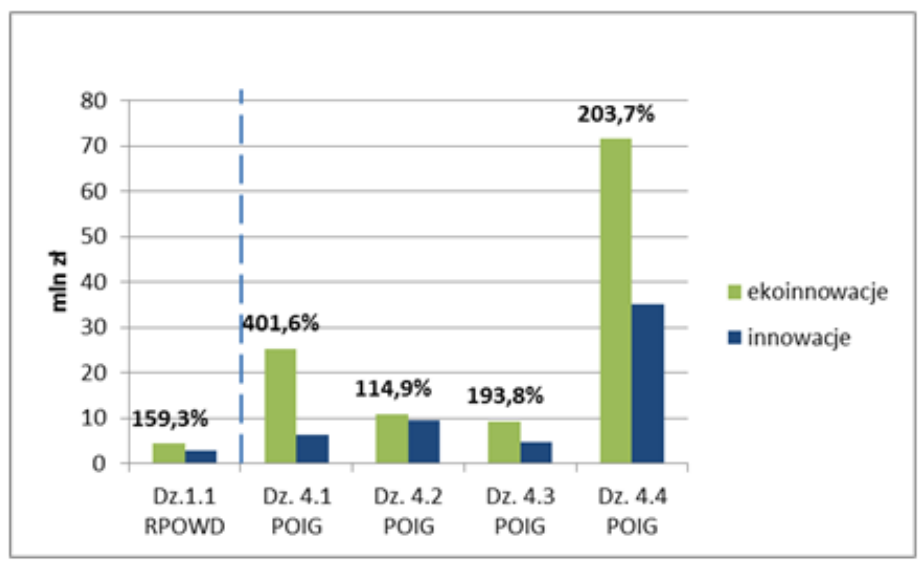

Rysunek 8. Porównanie średniego budżetu projektu

Źródło: Opracowanie własne 
Porównanie średniego budżetu dla każdego z projektów przedstawiono na $R y$ sunku 8. Podobnie jak w poprzednich przypadkach porównano działanie 1.1 RPO WD do działań 4.1, 4.2, 4.3, 4.4 PO IG. Jak pokazano na Rysunku 8, we wszystkich tych działaniach średni budżet dla projektów wdrażających ekoinnowacje jest wyższy od średniego budżetu innych projektów. W przypadku projektów w działaniu 4.1 PO IG wielkość budżetu projektów ekoinnowacyjnych jest czterokrotnie większa niż projektów innowacyjnych bez efektów ekologicznych. W przypadku działania 4.4 PO IG ta wielkość jest dwukrotnie większa. Wskazuje to znowu na znaczącą różnicę na korzyść projektów ogólnokrajowych. Tym razem nie należy jej odczytywać jednoznacznie negatywnie, gdyż wskazuje ona na nieco mniejsze koszty innowacji w przypadku projektów regionalnych niż w przypadku projektów krajowych.

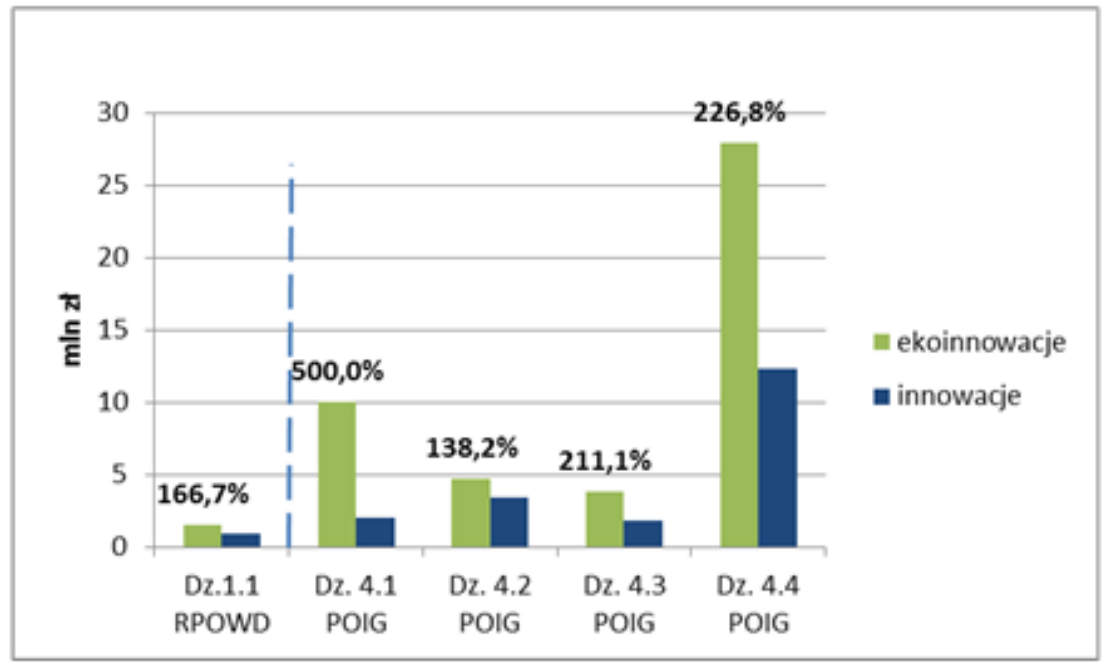

Rysunek 9. Porównanie średniej wielkości dofinansowania

Źródło: Opracowanie własne

Porównanie średniej wielkości dofinansowania (Rysunek 9) dla projektów ekoinnowacyjnych w województwie dolnośląskim jest wyższy o $66 \%$ niż w przypadku pozostałych projektów innowacyjnych. Tak jak w sytuacji porównania średniej wielkości budżetu przeznaczonego na projekty ekoinnowacyjne, podobnie jest w przypadku średniej wielkości dofinansowania projektów PO IG dla projektów ekoinnowacyjnych, gdyż ich wielkość jest znacznie większa niż projektów innowacyjnych bez efektów ekologicznych. Te wielkości odzwierciedlają dosyć dokładnie analogiczne wielkości średnich budżetów, a ich interpretacja może sprowadzić się do konstatacji, że projekty aplikowane regionalnie mają bardziej korzystny przelicznik wysokości budżetu do wielkości dotacji od projektów ogólnokrajowych w działaniu 4.1 i analogiczny jak w działaniu 4.4. 


\section{Podsumowanie}

Przeprowadzona analiza pokazuje dwa kluczowe zjawiska dla wdrażania ekoinnowacji przy współudziale funduszy UE. Po pierwsze, programy regionalne, jakim jest RPO WD, są adresowane przede wszystkim do sektora MŚP, który - z racji swej natury - nie jest liderem we wdrażaniu ekoinnowacji. Dominują tutaj przede wszystkim rozwiązania kluczowe dla konkurencyjności przedsiębiorstw, o możliwie znaczącym efekcie kosztowym, jakościowym, rynkowym czy technicznym. Efekty środowiskowe pojawiają się raczej wówczas, gdy samo oddziaływanie środowiskowe stanowi istotny element realizowanej działalności lub też sektor działania przedsiębiorstwa cechuje się wyższymi standardami czy oczekiwaniami środowiskowymi. Po drugie, ekoinnowacje wdrażane w projektach współfinansowanych ze środków RPO WD jawią się jako dosyć efektywne kosztowo przedsięwzięcia, mając nieco mniejsze ,narzuty” na efekty środowiskowe, niż ma to miejsce w przypadku projektów ogólnokrajowych.

Kolejnym krokiem przeprowadzonej analizy winno być przeliczenie efektów środowiskowych uzyskanych dzięki innowacjom na poniesione $\mathrm{w}$ tym zakresie wydatki, zwłaszcza ze środków publicznych. Taka ocena wymaga jednak zakończenia wszystkich projektów oraz skonfrontowania ich wskaźników wynikowych z założeniami dokumentacji projektowej.

Warto również przyjrzeć się całościowo efektom wdrażania ekoinnowacji, nie tylko współfinansowanym z funduszy strukturalnych UE i programów je wdrażających, ale również z innych źródeł. Oddzielną kwestią jest także wyodrębnienie efektów środowiskowych wdrażania innowacji w projektach samodzielnie finansowanych przez przedsiębiorstwa. Na chwilę obecną okresowa sprawozdawczość przedsiębiorstw nie pozwala na ujęcie tych efektów w skali całego kraju. Potrzeba zatem rozwiązań systemowych, które z jednej strony nie obciążą dodatkowo przedsiębiorstw działaniami sprawozdawczymi, a z drugiej dostarczą informacji, w jakim zakresie realizowane ekoinnowacje przyczyniają się do rozwiązywania problemów środowiskowych w Polsce.

\section{Literatura}

1. Anuszewska I., Podlejska K., Jackiewicz A., Filipek M. (2011), Zrównoważona produkcja $w$ działalności przedsiębiorstw. Raport z badania, Polska Agencja Rozwoju Przedsiębiorczości, Warszawa.

2. EC (2011), Communication from the Commission to the European Parliament, the Council, the European Economic and Social Committee and the Committee of the Regions, Innovation for a sustainable Future - The Eco-Innovation Action Plan (Eco-AP), European Commission, Brussels, 15.12.2011, COM(2011) 899 final.

3. http://www.mapadotacji.gov.pl/, Mapa Dotacji Unii Europejskiej, portal prowadzony przez Ministerstwo Rozwoju (dostęp: 30.06.2016).

4. Katoła A. (2012), Zrównoważony rozwój a ekoinnowacje, „Handel Wewnętrzny”, nr specjalny (lipiec-sierpień), t. 1, s. 68-77, http://www.wneiz.pl/katedry/kpsg/publikacje/handel _Szczecin_II_t1.pdf(dostęp: 13.01.2017).

5. $\quad$ Lisiecka K., Czyż-Gwiazda E. (2012), Eco-Innovations in Management of Organizations in Poland - Survey Results, [w:] Merli R. (ed.), Proceedings of 18th IGWT Symposium 
Technology and Innovation for a Sustainable Future, a Commodity Science Perspective, Rome, September 24-28th, AISME/ENEA.

6. Nitkiewicz T. (2012), Fostering Eco-Innovation Development and Implementation in Polish Companies Through Operational Program Innovative Economy, [w:] Knosala R. (red.), Innovations in Management and Production Engineering, Oficyna Wydawnicza Polskiego Towarzystwa Zarządzania Produkcją, Opole.

7. Nitkiewicz T. (2013), Ocena porównawcza wsparcia ekoinnowacji w przedsiębiorstwach $w$ województwach śląskim $i$ łódzkim, [w:] Pachura A. (red.), Srodowiska innowacyjne w perspektywie społeczno-kulturowej, Wydawnictwo Politechniki Częstochowskiej, Częstochowa, s. 104-115.

8. Ociepa-Kubicka A. (2015), EMAS - a Tool Supporting Eco-Innovations, LAP LAMBERT Academic Publishing, Saarbrucken.

9. RPO WD (2014), Regionalny Program Operacyjny Województwa Dolnośląskiego na lata 2007-2013 (RPO WD), Urząd Marszałkowski Województwa Dolnośląskiego, Wrocław, http://rpo2007-2013.dolnyslask.pl/fileadmin/user_upload/documents/14maj/26/RPO_WD_30 _04_2014.pdf (dostęp: 17.01.2017).

10. Smolnicki K., Lubaczewska S. (2013), Analiza wdrażania funduszy UE $w$ Regionalnym Programie Operacyjnym 2007-2013 Województwa Dolnoślaskiego pod katem realizacji zasady zrównoważonego rozwoju, Związek Stowarzyszeń Polska Zielona Sieć, ECORYS, http://ekoprojekty.pl/wp-content/uploads/2013/07/Analiza-RPO-2007-2013-woj.dolno\%C5\%9B1\%C4\%85skie.pdf (dostęp: 17.01.2017).

11. SOP PO IG (2013), Szczegółowy Opis Priorytetów Programu Operacyjnego Innowacyjna Gospodarka, 2007-2013. Narodowe Strategiczne Ramy Odniesienia na lata 2007-2013, Warszawa, https://www.poig.2007-2013.gov.pl/Dokumenty/Documents/SZOP_POIG_ver\% 2017_27062013.pdf (dostęp: 08.01.2017).

12. SOP RPO WD (2015), Szczegółowy Opis Priorytetów Regionalnego Programu Operacyjnego dla Województwa Dolnoślaskiego na lata 2007-2013 (Uszczegółowienie RPO WD), Wrocław, http://rpo2007-2013.dolnyslask.pl/fileadmin/user_upload/documents/15wrzesien/ 28/URPO_wrzesien_2015.pdf (dostęp: 08.01.2017).

13. Szpor A., Śniegocki A. (2012), Ekoinnowacje w Polsce. Stan obecny, bariery rozwoju, możliwości wsparcia, IBS, Fundacja im. Stefana Batorego, Warszawa, http://ibs.org.pl/app/ uploads/2016/03/IBS_Report_03_2012_pl.pdf (dostęp: 21.01.2017).

\title{
IMPLEMENTATION OF ECO-INNOVATION WITHIN REGIONAL OPERATIONAL PROGRAM OF DOLNOŚLĄSKIE VOIVODSHIP
}

\begin{abstract}
In the article, we address the issue of EU funds influence on the eco-innovation implementation process in business. Comparative analysis includes the assessment of the projects that have been realized in dolnośląskie voivodship with respect to eco-innovation level and in reference to nationwide level. The research is based on data from EU Support Map service covering the names, sectors, types, objectives and budgets of submitted projects that are co-financed from EU funds in 2007-2013 through Regional Operational Program of Dolnośląskie Voivodship (ROPDV) and Operational Program Innovative Economy (OPIE) frameworks. The aim of the article is to analyze the direct support to eco-innovation in companies through ROPDV in the years 2007-2013. For that purpose, all the projects are divided into eco-innovation and non-eco-innovation classes. In the following step, two classes are compared concerning their number, budget and EU funds support. Key variables differentiating two classes are: number of projects, total budget, average budget for the project and average share of EU funds in the budget.
\end{abstract}

Keywords: eco-innovation, EU structural funds in 2007-2013, OP Innovative Economy, ROP Dolnośląskie Voivodship 